Whirled along and broken to fragments by the rushing stream which seceived their decaying stems, the ruins of the forest reach the sea, and some few pieces float far from shore, beyond the area of deposited mud and drifted sand. Attacked by xylophagous mollusks, and sinking to the ocean-bed, one at least serves as the nucleus for organic growth and accretion. Not merely accretion, as in the case of an ironstone nodule, which grows more and more regularly ellipsoidal in the outer layers round a fern-frond; and not entirely of sponge-growth, though some traces of this tissue appear; for it would be difficult on this view to account for the reniform envelopment of the wood. Nor can we admit the idea of the flint being in this case secreted into a cavity of the chalk, with this bit of wood suspended in the axis of the hollow. But we may perhaps conceive that, after being surrounded wholly or partially by organic matter, and even buried in the Cretaceous deposit, the wood may have served as the local centre of attraction for siliceous solutions, such as have more than filled to solidity the tissues of sponges and the cavities of Fchinoidea, and thus to have undergone the complete 'petrifaction' through every cell and fibre which is frequently witnessed in other wood differently circumstanced. This kind of local attraction to particular tissues can be often exemplified in fossil wood which has become wholly calcareous, pyritous, or siliceous, just as the whole framework of sponge has become siliceous by attraction, continued after death, of the same substance which, while alive, it extracted from sea-water to build up its spicular skeleton.

OXFORD : June 17, 1865.

\title{
II. On the Genuineness of certain Fossils from the Macclesfield Drift-beds.
}

By R. D. Darbishire, B.A., F.G.S.

[Read before the Manchester Geological Society, March 29, 1865.]

A the last meeting of the Society, Mr. Plant made statements
respecting the supply of so-called fossil shells from the Drift
at Macclesfield, of a striking and curious character : he warned
geologists against certain specimens, on the grounds that some were
only recent shells sold as fossils, and others, though bearing the
appearance of Drift-fossils, were not only spurious as such from
Macclesfield, but were not even fossils at all, being nothing but the
results of an elaborate system of importation and manufacture :
forgeries, in fact, to meet a new demand. Mr. Plant allowed that
some of these frauds were well calculated to deceive even geolo-
gists, and quoted a statement that they had been successful at the
Museums of London, Liverpool, and Manchester. Besides the simple
introduction of recent shells, he specially reported a process of fetch-
ing such shells from recent beaches at Liverpool, Southport,
or Ireland (even the use of West Indian or African shells), the
breaking-up of the same, and the subjection of the fragments to
fire or acid, and a subsequent treatment by friction in a basket with 
gravel, "to give them the true Drift-character and the necessary red tinge.'

So authoritative an exposure of tricks that had been imposed on the would-be scientific. and on the guardians of public collections, ever anxious to fill their cases with novelties, could not but attract attention. The proceedings of the Society were reported in the Manchester papers on the lst of March, and the particulars of the Macclesfield frauds were speedily copied into several papers of general or scientific character in London, Liverpool, and elsewhere.*

Mr. Plant stated that a few shells and a number of fragments had occurred in the beds in question, but did not indicate what species he supposed to be thus genuine.

It happens that these Macclesfield fossils have occupied a good deal of my attention during the past winter, as being interesting in themselves, and as taking an important place amongst many similar series which I have studied for some years past. As I am myself convinced not only of the genuineness, but also of the peculiar interest, of the fossil shells discorered in the Macclesfield Drift-gravels during last year, and as I believe that Mr. Plant's statement is calculated to throw discredit, even to a far more serious extent than the forgeries themselves, upon those specimens which are veritable fossils of these deposits, I hare sought this opportunity of laying before the Society that received, and under whose name Mr. Plant published his revelations, a full list of the remains which I beliere to be of scientific value, that is to say genuine, together with such details and evidence in support of that view as I have at command. As my present object is solely the rindication of the character of the fossils in question, I will not now enter into details on the specially geological features and peculiarities of the Macclesfield Beds, or of their series of fossils.

For the purpose of my argument it is necessary, however briefly, to refer to the shell-bearing marine Drift of this and other localities. Within the limits of the 'Boulder-clay Formation,' as it is commonly seen in England, there are often found beds of sand and fine and coarse gravel, of rounded and water-worn pebbles, comparatively free from clayey admixture. These beds exhibit more or less distinct stratification, and frequently also those abundant and complicated layers of subordinate deposit, and those peculiar classifications of materials within short distances, which tell unmistakeably of the action of tidal or other currents of considerable, variable or intermittent power. These beds frequently yield to the painstaking observer a few much-worn bits of broken shells, often undistinguishable as to species; but here and there, under favourable circumstances, more completely preserved specimens may be met with, and a variety of forms discriminated.

These beds occur in several places in Lancashire, Derbyshire, and Cheshire, and in North Wales. They are exactly represented in

* Also in the Geological Magazine, vol, ii. p. 179. 
Scandinavia and Canada, and in many a beach and channel of the present seas.

The origin of these beds, which are sands and shingle rather than grasels, is unquestionably marine. Such beds are ranked by some observers as anterior to the Boulder-clay, by others as intermediate between a lower and an upper Boulder-clay, by others as a local or temporary modification of that deposit, or as the remains of a subsequent age.

It will be sufficient to mention particularly two noted instances of these deposits, each of which has been well examined and described. A bed containing remains of marine shells was discovered by the late Mr. Trimmer at the height of about 1,350 feet above the level of the sea, on Moel Tryfaen, near Carnarvon, one of the western spurs of the Snowdon range. To this deposit, which has lately been largely laid open as a mass of stratified drift some 40 feet thick, in the cuttings of the Alexandra Slate Quarry, I had the pleasure of directing the attention of Sir C. Lyell and the Rev. W. S. Symonds in the summer of 1863 .

Protected from the dissolving rainfall of ages by a superficial bed of clay, this ancient shingle lias yielded an abundant series of shells and fragments, to the number of nearly 60 species. There is no doubt of their genuine character. The greater part of them $I$ have myself taken from successive faces as exposed in the progress of the quarries. Full notes on the subject will be found in the proceedings of the Manchester Literary and Philosophical Society for November 1863 , and in the Appendix to the third edition of the 'Antiquity of Man.' The beds consist of fine and coarse sand, and a variety of shingle with pebbles varying in size from sand to paving-stones.

The second deposit of the kind I shall mention is exposed in the shore-cliffs north of the Gynn, between Blackpool and Fleetwood on the Lancashire coast, where it may be well seen for a mile or more in length, and many yards in thickness. Here also the formations consists of fine and coarse marine sand, and fine and coarse shingle. It exhibits in great variety the false-bedding and local assortment of materials above referred to. These beds have yielded a few shells and fragments of shells, the greater number of which are enumerated in Mr. Binney's paper On the Drift Deposits near Blackpool, in the 10th volume of the Memoirs of the Manchester Literary and Philosophical Society (1851-2). The remainder of the specimens named in the subjoined table from this locality have been found there by myself.

I will only add, before proceeding to the examination of the Macclesfield fossils, that the strata to which those specimens are attributed precisely correspond in character with the Moel Tryfaen and the Blackpool Beds, excepting only that at the Macclesfield Cemetery the beds present a section of 60 to 70 feet in depth, or nearly twice as great as that of either of the more western sites.

Similar beds are found in several places in the district about Macclesfield. One locality of peculiar interest was discovered by Mr. Prestwich, F.R.S., in an escarpment about half a mile east of 
the Setter Dog Inn, on the Buxton Road, at an elevation of between 1,100 and 1,200 feet above the level of the sea.

During the summer and autumn of last year, while the New Cemetery west of the Free Park at Macclesfield was being constructed, it became necessary to make a series of cuttings in the top and easterly declivities of the hill selected for its site, the ballast being tipped on to the lower edges of the hill, and along a new embanked road towards the town. In the course of these works an unusually complete exposure of the beds was effected, and a very large mass of material turned over.

From these cuttings, Mr. J. D. Sainter, a medical man of standing in Macclesfield, and a practised collector of geological specimens, and Mr. James Lowe, sen., also experienced in collecting, though not as a geologist, gathered together a large quantity of shells and fragments of shells. They frequently purchased from the workmen specimens which the latter stated they had dug up. The remains so collected were submitted for examination to gentlemen of the Geological.Survey then engaged in the district; and after they had signified their interest in the series, and had pointed out the presence of certain spurious specimens, it happened that the opportunity was afforded to me of making a very thorough examination of nearly the whole of the specimens thus got together.

Partly by a considerable purchase from Mr. Lowe, and partly by my own collections during repeated visits, I have acquired the series I now exhibit. The fragments which I collected were picked by myself from fresh faces of undisturbed beds, or from the slopes of natural or artificial falls.

Of the species marked in the following Table, as found in $\mathrm{Mr}$. Prestwich's patch, all were found by myself except those noted with an asterisk, which Mr. Lowe gathered from that place.

The bulk of this collection was exhibited by me at a meeting of the Manchester Literary and Philosophical Society in November last, and formed the subject of a short paper on the deposit and its fossils. In that paper due notice was taken of the introduction of recent Foreign and British shells.

There is no doubt that, as Messrs. Sainter and Lowe were very much interested in the discovery, and paid the workmen for specimens, many more were handed in to them than had been honestly dug up. Showy tropical species of Murex, Cypraa, Rotella, and many other shells of less remote but obviously of recent origin, were thus at first passed off upon these gentlemen, neither of whom is practised in fossil or recent conchology. Some of these spurious remains are evidently shells from some receut British sea-beach. 'The intrusion of these latter, particularly of shells which look as if they had long been chimneypiece ornaments or children's playthings, is the more to be regretted, as their presence tends to throw doubt upon several specimens which may after all be genuine.

But, in truth, it is only as to a very few of this class of specimens that anyone really skilled in recent and fossil conchology can for a moment hesitate. Shells or fragments with bright fresh gloss, or 
shells with more or less epidermis, or shells with the byssus of $M y t i-$ lus still adhering, could deceive no competent collector, howerer. carefully filled with sand.

Mr. Plant, however, detailed a fraud of more elaborate characternamely, the imitation of Drift-fossils by means of a process of importation and manufacture. I will not say that such a forgery could not be executed, but I doubt whether any Macclesfield workman has done it.

The fragments of shells which I present to-day with confidence as Drift-fossils from Macclesfield, not only represent with perfect fairness many pounds' weight which have passed through my hands at Mr. Lowe's, but with almost equal similarity like masses of the Moel Tryfaen remains.

Further, as appears from the Table, they reproduce with remarkable correspondence the groups or lots of species which occur in Carnarvonshire and at Blackpool.

Moreover, with even a yet more striking coincidence, these fragments from Macclesfield not only appear in almost identical proportions of frequency, but actually (as will be seen on comparing the specimens) continually repeat the conditions of fracture, wear, and preservation which characterise the Welsh and Lancashire specimens.

Supposing that the Macclesfield navigators could conduct a delicate mechanical and chemical process to the minute point of exact imitation, it is out of the question that any one of them should know exactly what species to use, or how to break and wear them to the genuine Drift pattern, or to mix them in true Drift proportions. It is impossible that they could introduce certain Arctic shells now extinct, or certain Southern shells of extreme rarity in British seas.

Now, though I picked out of Mr. Lowe's heap four or five untouched fragments of a foreign Venus, I have not in a single instance found a 'driftized' piece of any of several most common British beach-shells. There is, even amongst the spurious whole shells, a remarkable absence of such shells as Mya truncata, Solen, Tellina tenuis or fabula, Scrobicularia, Lutraria or Pecten varius. Those intruders which did occur are precisely such as might lave been brought home from some cheap excursion, to be treasured or neglected as the case might be, until the novel demand gave them a new value. Thus a perforated pebble, with fresh Saxicava, Mactra stultorum (the commonest of Lancashire beach-shells), Tellina solidula, Venus striatula, Patella vulgata, Turritella communis, Natica monilifera, Buccinum undatum, and Fusus gracilis were all brought forward-for immediate detection.

Lastly, the fragments of fossils are not sufficiently rare to make it easier to forge than find them. I have gathered a cubic inch in less than an hour several times; and one cannot suppose a deception so thorough-going that fossils, the fruit of so great an ingenuity, should be actually scattered and buried for visitors to find.

Upon the whole, I believe the accusation of the manufacture of Drift-fossils is altogether an invention. That it is so, one little 
remark of Mr. Plant's informer seems to me to prove. The author of the statement says the fragments, specially prepared with a coating of white-lime, were shaken in a basket of gravel, to give them the necessary red tinge. How this rubbing could be continued to the requisite length without removing the white-lime is doubtful. But after all, instead of having a red tinge, it so happens that these fossils have a peculiar and constant creamy-white colour. The redness is the fruit of the story-maker's own confusion between the 'gravel' according to the ordinary notions of gravel, and the gravel of the Macclesfield Drift-beds, which is a bright clean shingle.

That certain frauds have been more or less clumsily perpetrated, there is no doubt; but I repeat that they have not been such as to impose on a skilled and wary observer. They ought not, therefore, to be published without the definition of the true fossils, which, when shown to be reliable, constitute a material addition to the long and far-from-complete array of facts on which, sooner or later, a true theory of the Drift is to be founded.

Such frauds are, after all, not more than the ordinary fossil-buyer has been exposed to ever since and wherever there has been a market for specimens. The warning which $\mathrm{Mr}$. Plant has repeated will save some unskilful collectors from loss and disgrace. It was never more needful than now-a-days, when so much is stated and published with an assumption of scientific acumen and authority which most seriously deranges the deliberate progress of true science.

Before I refer you to the specimens themselves, it is only fair to the officers of the Museum of Practical Geology in Jermyn Street, to point out that they were the first to indicate the fact of the supply of spurious specimens; and to the gentlemen who preside over the Museum of the Philosophical Society and the Free Museum in Liverpool, to state that neither of them have ever seen the Macclesfield fossils. We at Manchester have certainly not been deceived on the subject.

If I seem to have taken up too much of the time of the Society, it is because the rehabilitation of a damaged reputation is necessarily a matter which requires a certain elaborateness of detail. 'The effort is in the present case the more needful, as the most remarkable fact in connection with these Macclesfield fossils, is the occurrence amongst them of certain species of southern type; a circumstance so new to the phenomena of the Drift as to challenge the closest inquiry, even had there been no suggestion of fraudulent endeavour.

A very short inspection* of the specimens will probably satisfy those who see them side by side, that the Macclesfield series precisely correspond, as to their geological and zoological facies, with the Moel Tryfaen and Blackpool fossils, and may fairly rank with them.

For the sake of a more elaborate proof, and of a wider audience, I submit the following digested Table of all the specimens in question

* Series of specimens are deposited in the Museums at Jermyn Street and Oxford. 

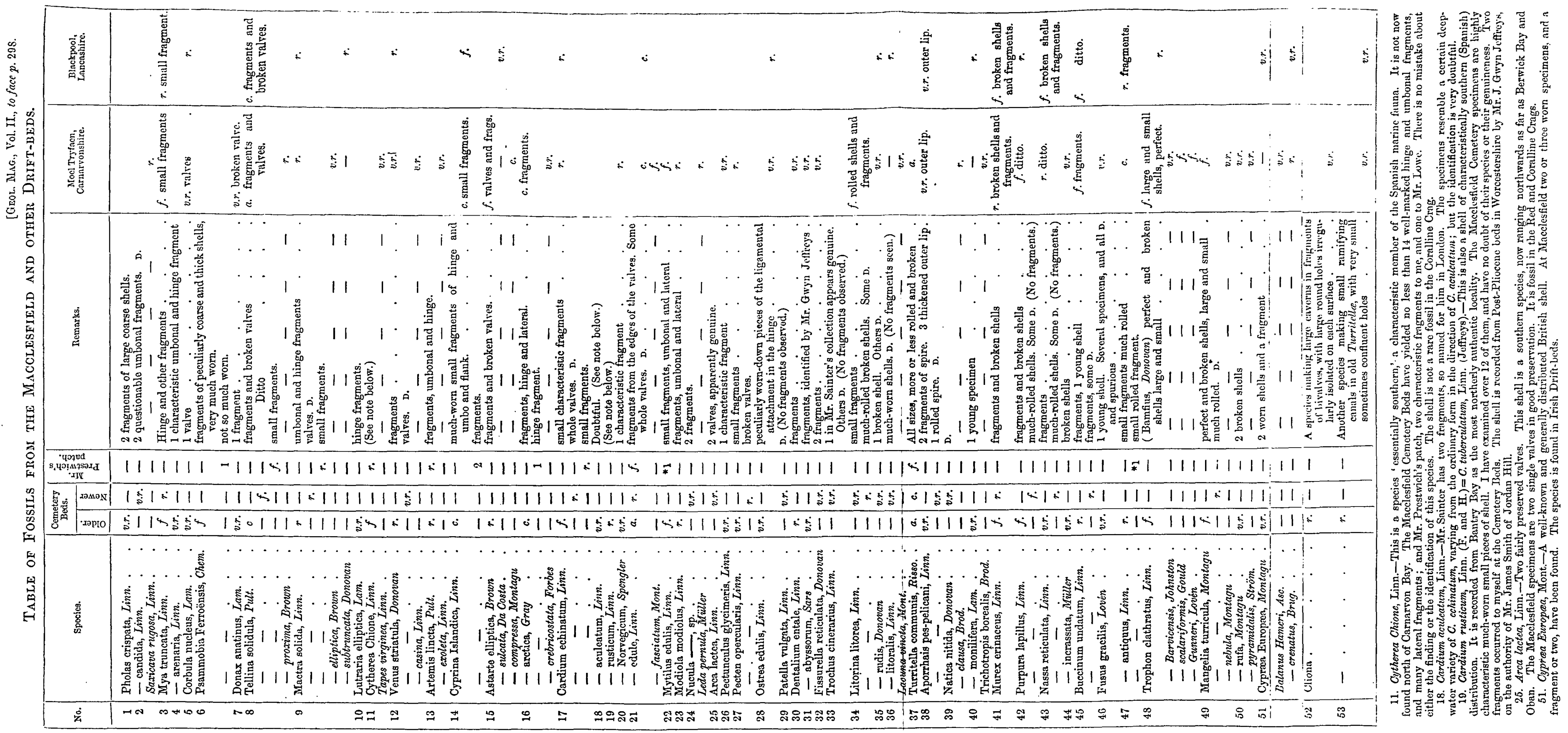
(except only manifestly spurious ones), in comparison with similar specimens, as recorded from the Welsh and Lancashire localities. Every single specimen, or fragment of a specimen, in the Macclesfield series now exhibited, has been minutely compared, not only with specimens of known Drift-fossils, but with recent shells, and also with the results of an elaborate examination, which I have carried on, of the character and forms in which fragments of shells present themselves on the beaches and in the bed of the present British seas.

A few specimens whose authenticity is suspicious are marked in the 'Remarks' column with $D$. It is not impossible that they may yet prove to be genuine.

Almost all these remains are broken into small fragments, and are much rolled and worn. A certain number may be put on one side, as presenting an appearance of greater comparative freshness, having lost less animal matter. These uniformly show signs of great attrition. They are noted on the 4 th column; the rest, noted in the 3rd column, look more completely mineralized, are often even friable, and all, except certain minute convolute shells, particularly broken up into small fragments. The latter series especially are almost always slightly adherent to the tongue.

While Mr. J. Gwyn Jeffreys' valuable Manual is still incomplete, I have thought it most convenient to use the nomenclature and arrangement of Messrs. Forbes and Hanley's 'British Mollusca.'

Scale of frequency :- $v$. $r$. very rare $(1$ to 3$) ; r$ rare $(3$ to 6$) ; f$. frequent (about 12); c. common (twice or thrice as numerous); $a$. abundant.

\section{A Tourist's Notes on the Surface-Geology of the LAKE-DISTRICT.}

By D. Mackintosh, F.G.S.

A LL geologists admit that the Lake-district of the North-west of A England has been several times under the sea since the first upheaval of the alternating sedimentary and volcanic rocks of which it is composed; and few would be disposed to question that during the repeated processes of elevation and subsidence, whether continuous or intermittent, the sides of the mountains and valleys of this district have been long exposed, at different levels, to the action of waves, tides, and currents. We have reason to suppose that the duration of the last or intra-glacial submergence was at least as long as the time which has since elapsed; and if during the latter the sea has done so much to indent and modify our coasts, may we not expect to find the most obvious traces of its former denuding influence in regions which have risen above its level? Yet some of the pluvial, fluvial, and glacial geologists of the present day would soon reduce the sea to a subordinate rank in the list of causes, were it not for the masterly advocacy of marine denudation which, with fresh arguments, may be found in the successive editions of the works of Sir Charles Lyell and Sir R. I. Murchison. 